Viewpoint

\title{
Cities of the Future? The Potential Impact of Artificial Intelligence
}

\author{
Eva Kassens-Noor $1, * \mathbb{B}$ and Arend Hintze ${ }^{2}$ \\ 1 School of Planning, Design and Construction and Global Urban Studies, Michigan State University, \\ East Lansing, MI 48824, USA \\ 2 Department for Complex Dynamical Systems and MircoData Analytics, Dalarna University, Högskolegatan \\ 2, 79131 Falun, Sweden; ahz@du.se \\ * Correspondence: ekn@msu.edu
}

Received: 1 April 2020; Accepted: 10 May 2020; Published: 13 May 2020

\begin{abstract}
Artificial intelligence (AI), like many revolutionary technologies in human history, will have a profound impact on societies. From this viewpoint, we analyze the combined effects of AI to raise important questions about the future form and function of cities. Combining knowledge from computer science, urban planning, and economics while reflecting on academic and business perspectives, we propose that the future of cities is far from being a determined one and cities may evolve into ghost towns if the deployment of AI is not carefully controlled. This viewpoint presents a fundamentally different argument, because it expresses a real concern over the future of cities in contrast to the many publications who exclusively assume city populations will increase predicated on the neoliberal urban growth paradigm that has for centuries attracted humans to cities in search of work.
\end{abstract}

Keywords: artificial intelligence; smart cities; future; work; autonomous vehicle

\section{Introduction}

The debate over whether form follows function [1] or function follows form [2] is centuries old. Starting in the 18th century, architects and engineers split in their pursuit to design cities either following the modern or the deconstructivist perspective. American skyscraper architect Louis Sullivan advocated for the former in that every building's shape should adapt to the form its interior serves. In contrast, Frank O Gehry, Rem Koolhaas, and Daniel Libeskind mastered the art of fitting any interior function into iconic buildings [3]. With the rise of modern technologies, the form-function debate is reviving over human needs and human behavior [4] and whether one can simply delink form and function given the flexibility of new technologies.

The smart city, sometimes called intelligent, virtual, or digital city, has been a vision for much of the 19th century rejuvenating the form-function debate. Smart cities are defined as cities in which information and communication technology (ICT) is merged with traditional infrastructures, coordinated, and integrated using new digital technologies [5]. ICT is tackling the wicked problems of urban operations, management, planning, development, and governance [6]. Early indications in the smart city pursuit signal a persistent marginalization process that reduces living quality in favor of neoliberal interests [7]. As smart cities continue to evolve, they become more vulnerable because global crises and systemic instability have been notoriously neglected within the smart city discourse [8]. As our argument will unfold, artificial intelligence is one of those impending neglects.

Artificial intelligence, like many revolutionary technologies in human history, will have a profound impact on societies [9], but, the impending fourth industrial revolution will be different from the first three: AI will have a profound impact on us as human beings [10]. AI here refers not only to data 
analytics and machine learning, which are experiencing a great hype due to the recent advances in deep learning, but also to its next installment: general-purpose AI, or machines that think like you and me or even exceed our human abilities. These machines do not only answer the question if we are alone in the universe-for sure not anymore-but may be a major threat to our socio-economic systems: AI makes human labor obsolete, which has traditionally attracted humans to cities [11,12].

\section{The Future of Work}

$\mathrm{AI}$ is expected to transform the nature of work radically. As several independent research projects by Oxford University, CitiBank, and McKinsey \& Company have recently shown, close to half of the current occupations are highly vulnerable to technical automation. For example, McKinsey examined 2000 work activities across 800 occupations and found that 47 percent of these tasks are automatable by simply adapting existing technology. McKinsey further found that $1 / 3$ of all tasks from $60 \%$ of all occupations can be automated already. This study demonstrates the impact of AI on potential job displacements and job loss. Assuming current technology trends continue, future technology will exponentially increase these work replacement predictions.

Of course, technical automatability does not translate into mass-scale automation overnight, as there are several other factors affecting the outcome. These include economic viability, necessary investments, labor rates, regulatory frameworks, and cultural influences. However, these research projects anonymously expect a gradual mass acceptance and adoption of many of these innovations in the coming decades. It is also worth noting that automation is expected to bring significant benefits, such as improved labor productivity, safety, as well as higher quality of products and services. If our history of prior revolutionary technologies is any indication, the eventual net impact on society is likely to be positive if benefits are equally distributed.

As AI transitions into our lives, it will have a profound impact on cities. Throughout modern history, cities have not only been the hub of economic activity and locus for many occupations but also underwent economic shifts toward specializations. Today many cities focus on a select number of industries: think of the role the finance sector plays in New York City, Pharma and R\&D in New Jersey, technology in Silicon Valley and San Francisco, and so forth. What would happen to these cities and localities if and when a vast majority of occupations in any of these industries begin to go through radical transformation due to $\mathrm{AI}$ and automation?

\section{The Form of Cities in the 22nd Century}

Much academic research focuses on improving the form of cities, so they can fulfill their presumed future function: adapt to the urban migration pressures of people in search of work [13]. By 2050, the UN predicts that more than two-thirds of the world's population will live in cities [14]. Cities already implement information technology (IT) infrastructure to enable AI applications for increased work efficiencies. Cities are spending billions (an estimated US $\$ 80 \mathrm{~B}$ by 2021) on smart infrastructure to prepare for the AI revolution [15], integrating AI into their urban service delivery options, waste management, energy utilization, crime prevention, environmental planning, among others [16].

One example is planning for connected autonomous vehicles (CAVs). Self-driving cars promise to improve efficiency and safety in cities [17], to reduce congestion and commute times [18], and to free up work time during commutes by 2040. With apps like Uber and Lyft, and ride-sharing services like Zipcar, we prepare for the advent of CAVs that function in cities. Cities already are experiencing decreases in their parking revenue and are selling off space in downtown to real estate developers in search of valuable workspace [19]. The pressure on work and vice versa living space to avoid the time-consuming commute is reflected in ever-increasing land prices [20].

In short, all trends lead to downtowns becoming more work-focused, cities are being equipped with $\mathrm{AI}$ infrastructure and redesigned to accommodate additional people, but we wonder what work remains for humans to do in cities? Isn't the vigorous argument for CAVs to increase commuting and 
working efficiency incomplete without accounting for job replacement effect? What is the function of cities if AI does what it is supposed to do?

\section{The Function of Cities in the 22nd Century}

On average, the number of working hours has decreased over time, while wages have either increased or stayed at similar levels. For instance, in the US, the average annual hours worked per person declined by $10 \%$ when comparing 2014 to 1950 . At the same time, average leisure time has increased when compared to the 1960s. One study found that on average, in the US, leisure time for men increased by 6-8 h per week and for women by 4-8 h per week from 1965 to 2003 [21].

This is a trend that is likely to continue and even accelerate with the mass-scale adoption of AI and automation technologies. As our work hours get replaced over time with leisure or non-work hours, which functions will cities have? Why do we live in or commute to cities, if not for work? Current publications take the fundamental functions of cities and their inhabitants for granted and predict ever-increasing urban populations that necessitates AI to create ever-smarter cities [22,23]. Given the future of work, and its implications on working hours and leisure time, we think urban dynamics will change dramatically and are not as clear cut as current views portray them. AI might change the function of cities through different levers:

\subsection{New in/out Migration Pressures}

Population pressures may lessen on cities unless cities take on new functions that replace work. With the advent of AI, real questions over whether the other benefits of cities, like entertainment and education, will be enough to keep cities as centers of human gathering. The Harvard economist Lawrence Katz predicts cities to become arts and cultural hubs creating a local artisanal economy [24]. However, this type and kind of spending has been historically cyclical, depending on households' disposable incomes [25]. If middle-income jobs are replaced by AI, spending will concentrate on food, housing, transportation, and healthcare [26] or the middle-income class may leave cites altogether when cities become unaffordable as property taxes outpace income growth [27].

For much of human history, socialization was associated with geographic proximity. With AI, geographical proximity is no longer needed. The internet provided connectivity, but when robots take over human-like functions, seniors may withdraw from city life [28]. As the wealthy age across cities, they may seek nature and solitude as the surrounding technology enables human closeness via AI.

\subsection{Economic Reasons}

Among other things, cities have been economic hubs for much of human history [29]. Technological disruptions have historically replaced some spaces by making products or services available digitally, e.g., travel agencies. AI will be no different, but much larger in scale and impact. It will drive people away from cities because the 4th industrial revolution will replace desk jobs, just like the third replaced human labor. Unemployment will rise in the short run that causes urban blight and homelessness [30]. Cities traditionally have provided support for the homeless. If the homeless become overwhelming for a city to serve, a local crisis may ensue [31].

A further economic angle to consider is "information asymmetry" that provides a competitive advantage for companies that use AI. Information asymmetry means companies collect data to model and predict "our" decisions what we as customers cannot $[32,33]$ This information asymmetry allows companies to increase prices for individuals at certain times using information about human preferences.

Economically, we might be in the midst of creating a local bubble in cities, which backfired as a minor recession during in 2009/2010 when the housing bubble burst. The AI bubble, however, is larger in scale encompassing work, housing, and retail—all things that attract humans to cities. 


\subsection{New Social-Human Dynamics}

If work ceases to exist, human nature will demand some other exploration mechanisms. Since the beginning of time, humans have been drawn to challenging environments. The very idea of AI is to give boring tasks to machines, so humans have time for more meaningful interactions and creative endeavors. In the beginning, AI is slated to replace mundane tasks. As AI evolves, it will take over problem-solving and cognitive functions leaving humans with tasks that foster instant instead of the more meaningful delayed gratification. In turn, this creates places that may be more unhappy as it becomes too easy to accomplish something meaningful in cities.

Many people define their purpose in life through their work, which is closely coupled to their economic success. But if work ceases to exist, humans will need to find an alternative purpose. Some of us, who are drawn to challenging environments, will deepen their sense of exploration and education. AI will free these people from mundane tasks and can even be used to create new challenges. Some of us prefer entertainment and leisure. It is easy to imagine how an oversimplification of our lives together with AI could lead to degeneration: the movie Wall-E depicting such a strange but possible future [34].

\section{Cities of the Future}

The future of cities will depend on how the different levers and resulting push and pull dynamics interact. Neither one of the possible new ways of life demand cities, instead they require human interactions and access to nature. The moral imperative makes the advent of AI seem inevitable (if we are capable of providing more safe, efficient, and reliable systems-we must). The competitive advantage argument (others will develop it anyway) is amplifying this development even though the potential risks of large-scale effects due to connectivity issues are massive. For example, one hacker can bring mobility to a standstill, or deployment mistakes hinder widespread adoption [35]. Finally, the legal systems, regulatory bodies, and insurance companies may need several decades to catch up to technological development.

If governments introduce $\mathrm{AI}$, we must create the foundations for ethical cities [36]. The redistribution of resources through social contracts such as conditional base income that stabilizes our socio-economic systems may be one among many others. Cities will develop differently across the globe, given their local industries [37]. Companies will replace tasks for which they spend less than human labor. If technology is too expensive or human labor too cheap in a given market, the status-quo will prevail. Thus, we will see a higher level of automation in advanced economy cities, while in much of the emerging markets cheap labor will initially prevent AI mass introduction in cities.

\section{Conclusions}

How will cities look like in the future? To the best of our knowledge, academic and business publications have argued for continued urban growth and created plans for the form and function serving additional populations. In contrast, we provide a counterviewpoint, arguing that artificial intelligence may turn our metropolises into ghost cities and the future of cities is far from being a determined one. Whether or not cities turn into ghost cities depends on the rate of AI adoption, policy regulations, and other unpredictable events, such as COVID-19. Thus, research is needed that combines different AI developments such as domotics and autonomous vehicles, integrates different push-and-pull dynamics explained above. We must analyze at what level of AI penetration the viability of cities is endangered. We should further lay out other mobility futures that account for AI's disruptive impacts. Research should also exemplify what could happen and analyze what is already happening to certain industries that begun the AI transformation, e.g., pharma. By analyzing the combined effect of the levers, researchers, public policy-makers, and practitioners can account for the impact of a global crisis and systemic instability that others argued are missing from the smart city discourse [8]. This means viewing cities as organically evolving entities rather than conforming to the totalizing technocratic norms [8]. 
Author Contributions: E.K.-N. conceptualized, investigated, and wrote the original draft as well as edited subsequent versions. A.H. conceptualized, investigated, and wrote the original draft as well as edited subsequent versions. All authors have read and agreed to the published version of the manuscript.

Funding: This research received no external funding.

Acknowledgments: We thank Mehdi Miremadi, a partner at McKinsey \& Company, for his valuable input, support, and intriguing perspectives.

Conflicts of Interest: The authors declare no conflict of interest.

\section{References}

1. Craven, J. The Meaning of 'Form Follows Function. Available online: https://www.thoughtco.com/formfollows-function-177237 (accessed on 8 April 2020).

2. Peñín Llobell, A.; Peñín Ibáñez, A. Can Our Cities Be Planned? The Function Follows the Form? The New York Experiences. Available online: https://upcommons.upc.edu/bitstream/handle/2117/108115/ISUF+Ponencia_ ing_def.pdf;jsessionid=9738D50657D17A3F8BD156B40165ABFD?sequence=1 (accessed on 1 March 2020).

3. Lewis, R.K. When Function Follows Form, the Result Can Be Innovative Architecture. Available online: https://www.washingtonpost.com/archive/realestate/2004/01/24/when-function-follows-form-theresult-can-be-innovative-architecture/439a678f-a623-4a09-a592-c6c11c61798d/ (accessed on 8 April 2020).

4. Wu, S. How is 'Form Follows Function' to 21st Century Design? Available online: https://uxdesign.cc/howis-form-follows-function-to-21st-century-design-335737a73305 (accessed on 8 April 2020).

5. Batty, M.; Axhausen, K.W.; Giannotti, F.; Pozdnoukhov, A.; Bazzani, A.; Wachowicz, M.; Portugali, Y. Smart cities of the future. Eur. Phys. J. Spec. Top. 2012, 214, 481-518. [CrossRef]

6. Bibri, S.E.; Krogstie, J. Generating a vision for smart sustainable cities of the future: A scholarly backcasting approach. Eur. J. Futures Res. 2019, 7, 5. [CrossRef]

7. Das, D. In pursuit of being smart? A critical analysis of India's smart cities endeavor. Urban Geogr. 2020, 41, 55-78. [CrossRef]

8. Kuecker, G.D.; Hartley, K. How Smart Cities Became the Urban Norm: Power and Knowledge in New Songdo City. Ann. Am. Assoc. Geogr. 2020, 110, 516-524. [CrossRef]

9. Yigitcanlar, T.; Desouza, K.C.; Butler, L.; Roozkhosh, F. Contributions and Risks of Artificial Intelligence (AI) in Building Smarter Cities: Insights from a Systematic Review of the Literature. Energies 2020, 13, 1473. [CrossRef]

10. Schwab, K. The Fourth Industrial Revolution. Available online: https://www.weforum.org/about/the-fourthindustrial-revolution-by-klaus-schwab (accessed on 8 April 2020).

11. Evolving our way to artificial intelligence. Available online: https://theconversation.com/evolving-our-wayto-artificial-intelligence-54100 (accessed on 1 March 2020).

12. What an Artificial Intelligence Researcher Fears about AI. Available online: https://theconversation.com/ what-an-artificial-intelligence-researcher-fears-about-ai-78655 (accessed on 1 March 2020).

13. Meredith, S. Two-Thirds of Global Population Will Live in Cities by 2050, UN Says. Available online: https://www.cnbc.com/2018/05/17/two-thirds-of-global-population-will-live-in-cities-by-2050-unsays.html (accessed on 8 April 2020).

14. Palanivel, T. Rapid Urbanisation: Opportunities and Challenges to Improve the Well-Being of Societies. Available online: http://hdr.undp.org/en/content/rapid-urbanisation-opportunities-and-challenges-improvewell-being-societies (accessed on 8 April 2020).

15. IDC Trackers. Worldwide Smart Cities Spending Guide. Available online: https://www.idc.com/tracker/ showproductinfo.jsp?prod_id=1843 (accessed on 8 April 2020).

16. West, D.M.; Allen, J.R. How Artificial Intelligence Is Transforming the World. Available online: https://www. brookings.edu/research/how-artificial-intelligence-is-transforming-the-world/ (accessed on 1 March 2020).

17. Calem, R.E. How will Self-Driving Cars Impact Cities? Available online: https://www.cta.tech/News/i3/ Articles/2019/July-August/How-will-Self-driving-Cars-Impact-Cities.aspx (accessed on 1 March 2020).

18. Litman, T. Autonomous Vehicle Implementation Predictions-Implications for Transport Planning. Available online: https://www.vtpi.org/avip.pdf (accessed on 1 March 2020). 
19. Bargain-Hunting Robocars Could Spell the End for Downtown Parking-Cities Need to Plan Ahead Now. Available online: https://heconversation.com/bargain-hunting-robocars-could-spell-the-end-fordowntown-parking-cities-need-to-plan-ahead-now-121358 (accessed on 1 March 2020).

20. Data \& Toolkits: Land and Property Values in the U.S. Available online: https://www.lincolninst.edu/researchdata/toolkits/content-unavailable (accessed on 1 March 2020).

21. Aguiar, M.; Hurst, E. Measuring Trends in Leisure: The Allocation of Time Over Five Decades. Available online: https://www.nber.org/papers/w12082 (accessed on 8 April 2020).

22. Artificial Intelligence and Life in 2030. Available online: https://ai100.stanford.edu/sites/g/files/sbiybj9861/f/ ai_100_report_0831fnl.pdf (accessed on 8 April 2020).

23. Microsoft. Smart City Technologies. Available online: https://www.microsoft.com/en-us/industry/ government/smart-cities (accessed on 8 April 2020).

24. Publications of Lawrence Katz, Elisabeth Allison Professor of Economics. Available online: https://scholar. harvard.edu/lkatz/publications?page=1 (accessed on 8 April 2020).

25. Nicols, B. Expenditures on Admissions to the Arts, Movies, Sporting Events, and Other Entertainment. 2017. Available online: https:/www.bls.gov/spotlight/2017/expenditures-on-arts-movies-sporting-events-andother-entertainments-and-recreational-activities/home.htm (accessed on 1 March 2020).

26. U.S. Bureau of Labor Statistics. Economic News Release: Consumer Expenditure 2018. 2019. Available online: https://www.bls.gov/news.release/cesan.nr0.htm (accessed on 1 March 2020).

27. Berg, A. Home is Where the Hurt is: How Property Taxes Are Crushing Illinois' Middle Class. Illinois Policy. Available online: https://www.illinoispolicy.org/story/home-is-where-the-hurt-is-how-property-taxes-arecrushing-illinois-middle-class/ (accessed on 1 March 2020).

28. Foster, M. Aging Japan: Robots May Have Role in Future of Elder Care. Available online: https://www.reuters.com/article/us-japan-ageing-robots-widerimage/aging-japan-robots-may-haverole-in-future-of-elder-care-idUSKBN1H33AB (accessed on 1 March 2020).

29. McKinsey Global Institute. Urban World: Mapping the Economic Power of CIties. Available online: https://www.mckinsey.com/ \{\}/media/mckinsey/featured\%20insights/urbanization/urban\%20world/ mgi_urban_world_mapping_economic_power_of_cities_full_report.ashx (accessed on 1 March 2020).

30. Holland, G.; Smith, D.L.A. County Homelessness Jumps a 'Staggering' 23\% as Need Far Outpaces Housing, New Count Show. Available online: https://evitarus.com/wp-content/uploads/2016/07/L.A.-Countyhomelessness-jumps-a-staggering-23.pdf (accessed on 8 April 2020).

31. Varner, C.; Lurie, I.; Prisinzano, R. Millionaire Migration and the Taxation of the Elite: Evidence from Administrative Data. Available online: https:/sociology.stanford.edu/publications/millionaire-migrationand-taxation-elite-evidence-administrative-data-0 (accessed on 8 April 2020).

32. Allam, Z. The Emergence of Anti-Privacy and Control at the Nexus between the Concepts of Safe City and Smart City. Smart Cities 2019, 2, 96-105. [CrossRef]

33. European Commission. White Paper on Artificial Intelligence: A European Approach to Excellence and Trust. Available online: https://ec.europa.eu/info/publications/white-paper-artificial-intelligence-europeanapproach-excellence-and-trust_en (accessed on 6 May 2020).

34. Stanton, A.; Reardon, J. Wall-E; Pixar Animation Studios and Walt Disney Pictures: Emeryville, CA, USA, 2008.

35. Davis, K.J. Food Delivery Robots Pulled from Pitt Campus after Backlash about Mobility. Available online: https://www.wesa.fm/post/food-delivery-robots-pulled-pitt-campus-after-backlash-about-mobility\# stream/0 (accessed on 8 April 2020).

36. Barrett, B.F.D.; Horne, R.; Fien, J. The Ethical City: A Rationale for an Urgent New Urban Agenda. Sustainability 2016, 8, 1197. [CrossRef]

37. Polèse, M. Five Principles of Urban Economics. Available online: https://www.city-journal.org/html/fiveprinciples-urban-economics-13531.html (accessed on 8 April 2020).

(C) 2020 by the authors. Licensee MDPI, Basel, Switzerland. This article is an open access article distributed under the terms and conditions of the Creative Commons Attribution (CC BY) license (http://creativecommons.org/licenses/by/4.0/). 